Jurnal Pendidikan dan Pemberdayaan Masyarakat
Volume 3 - Nomor 2, November 2016, (187-196)

\title{
STRATEGI PENGEMBANGAN INOVASI PROGRAM PENDIDIKAN NON FORMAL SEBAGAI BEST PRACTICES BAGI PUSAT KEGIATAN BELAJAR MASYARAKAT
}

\author{
Muhammad Arief Rizka ${ }^{1}$ *, Rila Hardiansyah ${ }^{2}$ \\ ${ }^{12}$ Program Studi Pendidikan Luar Sekolah, Fakultas Ilmu Pendidikan IKIP Mataram. Jalan \\ Pemuda 59A Mataram, Nusa Tenggara Barat, Indonesia \\ * Korespondensi Penulis. Email: m.ariefrizka@gmail.com
}

\begin{abstract}
Abstrak
Tujuan penelitian ini adalah untuk memetakan inovasi program PNF yang dikembangkan dan menganalisis strategi yang digunakan dalam mengembangkan inovasi program PNF yang dapat dijadikan sebagai best practices bagi PKBM di Kota Mataram. Penelitian ini menggunakan metode deskriptif dengan pendekatan kualitatif. Unit analisis dalam penelitian ini adalah PKBMPKBM di Kota Mataram yang ditentukan secara purposif. Sumber data dalam penelitian ini yakni Pengelola PKBM, Tutor, dan Penilik PNF Kota Mataram. Teknik pengumpulan data menggunakan pedoman wawancara, pedoman observasi, dan dokumentasi. Analisis data penelitian dilakukan dengan menggunakan model analisis interaktif. Teknik keabsahan data dengan menggunakan triangulasi sumber dan diskusi dengan teman sejawat. Hasil penelitian ini mendeskripsikan bahwa (1) inovasi program PNF yang dikembangkan oleh PKBM-PKBM di Kota Mataram cukup variatif dan berbasis pada kebutuhan riil masyarakat dengan fokus inovasi program pada dimensi pelayanan, peningkatan kapasitas, dan kesejahteraan masyarakat. (2) Strategi yang digunakan dalam pengembangan inovasi program PNF pada PKBM di Kota Mataram antara lain yaitu startegi partisipatif, strategi persuasif, dan strategi pemetaan sosial yang dimana penggunaan strategi tersebut sejauh ini telah optimal dalam mengembangkan program PNF yang inovatif di masingmasing PKBM tersebut.
\end{abstract}

Kata Kunci: strategi pengembangan, inovasi, program PNF.

\section{DEVELOPMENT STRATEGY OF NON-FORMAL EDUCATION PROGRAM INNOVATION AS BEST PRACTICES FOR COMMUNITY LEARNING CENTER}

\begin{abstract}
This research aimed to map innovation of NFE program which was developed by CLC's and analyse strategy which was used in developing innovation of PNF program that could become best practice for CLC's at Mataram city. This research used descriptive method with qualitative approach. Analysis unit in this research was all CLC's at Mataram city which determined as purposive. Data sources in this research namely CLC's management, tutor, ad owner of NFE Mataram city. Technique of data collection used interview, observation and documentation. The data analysis was conducted with using interactive analysis. Tehnique of data validity with using sources of triangulation and discussion with friends. The result of research in describing that (1) innovation of NFE program which developed by all CLC's Mataram city was quite variety and based on community real needed with focusing on innovation program on serving dimension, improving capacity, and public welfare. (2) strategy which used in developing innovation of NFE program at CLC's Mataram city such as participatory strategy, persuasive strategy, and social mapping strategy which used strategy mention as far as this strategy was optimal in developing inovative NFE program on each CLC's.
\end{abstract}

Keywords: development strategy, innovation, nonformal education program

How to Cite: Rizka, M., \& Hardiansyah, R. (2016). Strategi pengembangan inovasi program pendidikan nonformal sebagai best practices bagi pusat kegiatan belajar masyarakat. Jurnal Pendidikan dan Pemberdayaan Masyarakat, 3(2), 187-196. doi:http://dx.doi.org/10.21831/jppm.v3i2.10745

Permalink/DOI: http://dx.doi.org/10.21831/jppm.v3i2.10745

Copyright (c) 2016, JPPM, Print ISSN: 2355-1615, Online ISSN: 2477-2992 
Jurnal Pendidikan dan Pemberdayaan Masyarakat, 3 (2), November 2016 - 188

Muhammad Arief Rizka, Rila Hardiansyah

\section{PENDAHULUAN}

Dinamika kebutuhan belajar masyarakat yang semakin variatif dan memiliki diferensiasi pola, menunjukkan bahwa masyarakat telah mulai proaktif untuk mengembangkan wadah-wadah pembelajaran yang aspiratif terhadap kebutuhan belajarnya. Untuk memenuhi kebutuhan belajar masyarakat yang heterogen tersebut, tidak cukup hanya dilayani melalui satuan pendidikan formal (sekolah), akan tetapi membutuhkan peran satuan pendidikan non fomal (PNF) untuk dapat menjawab kebutuhan belajar masyarakat yang dinamis tersebut. Pusat Kegiatan Belajar Masyarakat (PKBM) merupakan salah satu satuan PNF yang secara konseptual berbasis masyarakat dan dituntut untuk selalu melakukan inovasiinovasi dalam upaya mewujudkan programprogram pemberdayaan masyarakat yang lebih baru, berkarakter transformatif, dan dapat menjadi best practices dengan tidak meninggalkan karakteristik kearifan dan keunggulan lokal sebagai added values untuk mencerdaskan dan mensejahterahkan kehidupan masyarakat (Rizka \& Tamba, 2015).

Kondisi aktual PKBM mendeskripsikan suatu perkembangan yang positif terkait dengan kuantitas, serta respon yang cukup aktif dari masyarakat terhadap eksistensi PKBM sebagai salah satu agen pemberdayaan masyarakat. Berdasarkan data BPPNFI Regional V Mataram (2010) menunjukkan bahwa jumlah PKBM di wilayah provinsi NTB setiap tahun semakin meningkat. Perkembangan jumlah lembaga PKBM tersebut tentunya dapat menjadi harapan positif untuk peningkatan pelayanan pendidikan dan pemberdayaan kepada masyarakat. Akan tetapi, PKBM yang berdiri atas dasar inisiasi dari masyarakat pada keadaan sekarang ini belum berbanding lurus dengan capaiancapaian kualitatif dalam konteks pengembangan inovasi program PNF yang menjadi program primernya. Karakteristik inovasi program yang lebih responsif sebagai jawaban atas kebutuhan belajar masyarakat yang variatif dan kompleks belum terlihat secara faktual. PKBM masih eksis dengan pola 'konformitas' yang di indikasikan dengan program-program yang bersifat homogen dengan turunan program pemerintah melalui mekanisme petunjuk teknis (juknis) dan petunjuk pelaksanaan (juklak).

Program PNF yang inovatif diselenggarakan oleh PKBM masih kurang optimal dikembangkan, hal ini salah satunya disebabkan oleh penerapan strategi pengembangan program yang masih kurang terpola dengan baik dan penyelenggaraan program antar PKBM yang menunjukkan adanya kesamaan pengambilan prioritas keputusan mengenai pelaksanaan program PNF yang dicirikan dengan sikap reaktif pengelola program terhadap tawaran pemerintah. Selain itu, pengelola program di PKBM masih bergantung pada gagasan dan sarana prasarana yang disediakan oleh pemerintah (Suharta, dkk., 2009). Di sisi lain, pengelolaan kelembagaan PKBM yang mencakup fungsi perencanaan program, manajemen sumberdaya, kemampuan evaluasi, pengembangan kapasitas lembaga, dan kemampuan diseminasi produk PNF belum dilakukan dengan efektif dan optimal (Tohani, 2010).

Berdasarkan pada latar belakang tersebut, dipandang penting untuk melakukan penelitian yang diarahkan untuk melakukan analisis strategi pengembangan inovasi program PNF yang dilakukan oleh PKBM di Kota Mataram yang dapat dijadikan best practices (contoh yang dapat diaplikasikan) bagi PKBM lainnya, sehingga upaya pengembangan inovasi program PNF dapat diwujudkan oleh setiap PKBM sebagai bentuk memberikan jaminan mutu dan sekaligus menjawab kebutuhan pelayanan pendidikan bagi masyarakat. Adapun tujuan dilakukannya penelitian ini antara lain untuk memetakan inovasi program PNF yang dikembangkan oleh PKBM di Kota Mataram dan menganalisis strategi pengembangan inovasi program PNF yang digunakan oleh PKBM di Kota Mataram yang dapat dijadikan sebagai best practices bagi PKBM lainnya.

\section{METODE}

Metode yang digunakan dalam penelitian ini adalah metode deskriptif dengan pendekatan penelitian kualitatif. Penggunaan metode deskriptif kualitatif ini berupaya mencatat permasalahan yang muncul terkait dengan objek yang diteliti secara seksama, 


\section{Jurnal Pendidikan dan Pemberdayaan Masyarakat, 3 (2), November 2016 - 189}

Muhammad Arief Rizka, Rila Hardiansyah

kemudian masalah tersebut dideskripsikan apa adanya. Metode ini berupaya mendeskripsikan objek penelitian sesuai dengan kondisi dilapangan dalam bentuk kalimatkalimat berupa keterangan atau proposisiproposisi dari responden sesuai dengan kenyataan yang ada (Mulyana, 2001, p.109). Untuk memperoleh data penelitian yang faktual objektif dan komprehensif, penelitian ini juga didukung oleh data-data kuantitatif untuk mempermudah pemahaman terhadap aspek kualitatif data.

Unit analisis dalam penelitian ini adalah lembaga Pusat Kegiatan Belajar Masyarakat (PKBM) yang berada di Kota Mataram yang telah ditentukan secara purposif. Instrumen pengumpulan data yang digunakan dalam penelitian ini adalah peneliti sendiri sebagai instrumen kunci (key instrument) dengan didukung oleh pedoman wawancara, observasi, dan dokumentasi. Teknik analisis data yang digunakan dalam penelitian ini adalah teknik analisis data kualitatif model interaktif dari Miles \& Huberman (2007). Analisis data model interaktif meliputi: 1) Reduksi data berarti menelaah seluruh data yang tersedia dari berbagai sumber data baik dari wawancara, observasi, dan dokumentasi mengenai objek penelitian. Data-data dirangkum, dipilih hal-hal yang pokok, difokuskan pada hal yang penting, dicari tema dan polanya dan membuang yang tidak perlu. Data dalam satuan-satuan dimasukkan dalam kategori; (2) Penyajian data dilakukan dengan membentuk uraian singkat, bagan dan hubungan antar kategori, flowchart dan sejenisnya; dan (3) langkah selanjutnya adalah memberikan verifikasi atau penafsiran pada data untuk mencari makna dan implikasi yang lebih luas dari hasil penelitian. Dalam penelitian ini, validasi data penelitian dilakukan dengan pengujian terhadap keabsahan data melalui teknik triangulasi sumber dengan mengutamakan check-recheck, crossrecheck antar sumber data satu dengan lainnya (Moleong, 2007, p. 178).

\section{HASIL DAN PEMBAHASAN}

\section{Inovasi Program PNF}

Inovasi Pogram Pendiidkan Non Formal (PNF) adalah suatu program pendidikan yang diselenggarakan oleh PKBM dengan inisiatif dan perancangan program berbasis pada kebutuhan masyatakat dan potensi lingkungan. Inovasi disini dapat dilihat dari program yang dirancang berbeda dengan program-program pada umumnya (program dari pemerintah). Karakteristik atau indikator dari inovasi program PNF yang diselenggarakan oleh PKBM antara lain, yaitu; (1) memiliki kekhasan atau ciri tertentu (sesuai dengan potensi lingkungan); (2) memiliki nilai kreasi; (3) memiliki perencanaan; dan (4) memiliki tujuan yang kongkrit.

Selain dari jabaran indikator tersebut, dalam penelitian ini juga berupaya untuk mendeskripsikan secara komprehensif pelaksanaan inovasi program PNF yang diselenggarakan pada PKBM-PKBM yang diteliti, yakni mengenai detail informasi tentang inovasi program yang dilakukan serta sejauh mana inovasi program tersebut dapat dikatakan sebagai sebuah inovasi yang memenuhi sejumlah kriteria dan menjadi best practice yang dapat menjadi pelajaran (lesson learned) bagi PKBM-PKBM lainnya. Oleh karena itu, kombinasi dari berbagai pendekatan telah dilakukan agar deskripsi komprehensif yang diinginkan tersebut dapat tercapai.

Dalam menyelenggarakan program pendidikan, PKBM dituntut untuk mengembangkan program-program PNF yang inovatif sebagai manifestasi dari eksistensi PKBM yang ingin menjadi bagian strategis dalam pemecahan permasalahan yang ada di masyarakat. Dalam mengatasi berbagai permasalahan kebutuhan belajar masyarakat tidak cukup hanya bertumpu pada programprogram pendidikan yang bersifat "instruksionalis', tetapi sangat penting untuk melakukan upaya-upaya improvisasi program bahkan sampai pada inovasi program yang berbasis pengembangan potensi individu dan lingkungan.

Berdasarkan pada data penelitian, inovasi program yang telah dilakukan oleh PKBM-PKBM yang menjadi lokasi penelitian cukup variatif. Hal ini tidak terlepas dari komitmen para pengelola PKBM untuk menjadikan satuan PNF tersebut sebagai wadah penciptaan program-program pendidikan berbasis masyarakat. Pendekatan yang dila- 
kukan untuk memetakan inovasi program PNF pada PKBM-PKBM yang diteliti dengan mencari informasi melalui data dokumentasi, melakukan wawancara mendalam dengan para pengelola PKBM, dan melakukan pengamatan untuk memperoleh informasi yang relevan dan dapat dipercaya. Selain itu, pendekatan yang dilakukan dalam mengelompokkan inovasi program PNF pada PKBM-PKBM yang diteliti dengan menggunakan kriteria tertentu seperti locus (internal dan eksternal PKBM), focus (terkait dengan proses pelayanan program, peningkatan kapasitas dan kesejahteraan bagi masyarakat), objektif (efektivitas-efisiensi pengelolaan program, penanganan masalah sosial ekonomi masyarakat), dan metode pelaksanaan (melibatkan partisipasi masyarakat atau pengelola program).

Inovasi program PNF yang telah dikembangkan oleh PKBM di Kota Mataram (yang menjadi locus penelitian) dapat diidentifikasi sebagai berikut. Berdasarkan data penelitian tersebut, menunjukkan bahwa terdapat beberapa inovasi program yang telah dikembangkan oleh PKBM-PKBM yang berada di Kota Mataram. Inovasi program PNF yang dikembangkan oleh PKBM tersebut telah dipetakan dengan berdasarkan pada parameter atau kriteria best practice. Kriteria yang dimaksud antara lain programprogram yang dikembangkan tersebut memiliki kekhasan (kerakteristik) dibandingkan dengan program-program PNF lainnnya, memiliki nilai kreasi (kebaruan), terdapat perancangan program yang sistematis, dan memiliki tujuan yang kongkrit. Selain itu, dalam penelitian ini juga berupaya untuk mendeskripsikan inovasi program yang dikembangkan oleh PKBM di Kota Mataram dengan melihat pada aspek locus, fokus, objektivitas, dan metode pelaksanaannya sehingga penjabaran inovasi program PNF tersebut dapat menjadi lebih relevansif.

Tabel 1. Inovasi Program PNF pada PKBM di Kota Mataram

\begin{tabular}{cll}
\hline PKBM & \multicolumn{1}{c}{ Inovasi Program } & \multicolumn{1}{c}{ Sasaran } \\
\hline \multirow{2}{*}{ Al-Kautsar } & Pelatihan keterampilan asesoris perahu nelayan & $\begin{array}{l}\text { pemuda/pemudi } \\
\text { pengangguran }\end{array}$ \\
\cline { 2 - 3 } & $\begin{array}{l}\text { Pemberdayaan perempuan melalui pelatihan kewirausahaan } \\
\text { berbasis pengolahan ikan laut }\end{array}$ & ibu-ibu rumah tangga \\
\hline \multirow{2}{*}{ Al-Hidayah } & Pelatihan kecakapan hidup ternak ikan lele & pemuda pengangguran \\
\cline { 2 - 3 } & Kursus modes busana muslim & perempuan pengangguran \\
\hline Sinar Harapan & Kelompok Usaha Bersama (KUB) tata rias pengantin & pemuda pengangguran \\
\hline \multirow{2}{*}{ Terampil } & Bina keluarga sakinah & warga masyarakat \\
\cline { 2 - 3 } & Taman Anak Sejahtera (TAS) & anak balita kurang mampu \\
\hline Sintung & Kelompok Belajar Usaha (KBU) aneka jajanan tradisional & perempuan pengangguran \\
\hline
\end{tabular}

Tabel 2. Inovasi Program PNF di PKBM berdasarkan Locus, Fokus, Objektif, dan Metode

\begin{tabular}{|c|c|c|c|c|c|c|c|c|c|}
\hline \multirow{2}{*}{ No } & \multirow{2}{*}{ Nama Program } & \multicolumn{2}{|c|}{ Locus } & \multicolumn{3}{|c|}{ Fokus } & Objektif & \multicolumn{2}{|c|}{ Metode } \\
\hline & & Ekst & Int & Pel & Kap & Kesj & Ef SosEko & Parmas & Tdk \\
\hline 1 & $\begin{array}{l}\text { Pelatihan keterampilan asesoris } \\
\text { perahu nelayan }\end{array}$ & & $\sqrt{ }$ & & $\sqrt{ }$ & & $\sqrt{ }$ & $\sqrt{ }$ & \\
\hline 2 & $\begin{array}{l}\text { Pemberdayaan perempuan melalui } \\
\text { pelatihan kewirausahaan berbasis } \\
\text { pengolahan ikan }\end{array}$ & & $\sqrt{ }$ & & & $\sqrt{ }$ & $\sqrt{ }$ & $\sqrt{ }$ & \\
\hline 3 & $\begin{array}{l}\text { Pelatihan kecakapan hidup budidaya } \\
\text { ikan lele }\end{array}$ & & $\sqrt{ }$ & & & $\sqrt{ }$ & $\sqrt{ }$ & $\sqrt{ }$ & \\
\hline 4 & Kursus modes busana muslim & & $\sqrt{ }$ & & & $\sqrt{ }$ & $\sqrt{ }$ & $\sqrt{ }$ & \\
\hline 5 & $\begin{array}{l}\text { Kelompok Usaha Bersama (KUB) tata } \\
\text { rias pengantin }\end{array}$ & $\sqrt{ }$ & & & & $\sqrt{ }$ & $\sqrt{ }$ & $\sqrt{ }$ & \\
\hline 6 & Bina keluarga sakinah & $\sqrt{ }$ & & $\sqrt{ }$ & & & $\sqrt{ }$ & & $\sqrt{ }$ \\
\hline 7 & Taman Anak Sejahtera (TAS) & & $\sqrt{ }$ & $\sqrt{ }$ & & & $\sqrt{ }$ & & $\sqrt{ }$ \\
\hline 8 & $\begin{array}{l}\text { Kelompok Belajar Usaha (KBU) } \\
\text { aneka jajanan tradisional }\end{array}$ & & $\sqrt{ }$ & & & $\sqrt{ }$ & $\sqrt{ }$ & $\sqrt{ }$ & \\
\hline
\end{tabular}




\section{Jurnal Pendidikan dan Pemberdayaan Masyarakat, 3 (2), November 2016 - 191}

Muhammad Arief Rizka, Rila Hardiansyah

Keterangan :

$\begin{array}{ll}\text { Ekst } & =\text { Ekternal PKBM } \\ \text { Int } & =\text { Internal PKBM } \\ \text { Pel } & =\text { Pelayanan } \\ \text { Kap } & =\text { Peningkatan Kapasitas } \\ \text { Kesj } & =\text { Peningkatan Kesejahteraan } \\ \text { Ef } & =\text { Efektivitas-Efisiensi }\end{array}$

SosEko = Penanganan Masalah Sosial Ekonomi

Parmas $=$ Partispasi Masyarakat

Tdk = Tidak Partisipatif

Berdasarkan data penelitian tersebut, terdapat sejumlah temuan terkait dengan adanya inovasi program yang telah dikembangkan oleh PKBM-PKBM di Kota Mataram. Temuan tersebut menunjukkan bahwa terdapat setidaknya 8 (delapan) program yang dapat dikatan sebagai suatu inovasi dilihat dari locus, focus, objektif, dan metode pelaksanaannya. Dari hasil penelaahan hasil penelitian, dapat dijelaskan bahwa inovasi program PNF yang dikembangkan oleh PKBM-PKBM yang menjadi unit analisis penelitian ini lebih didominasi oleh program yang memiliki locus atau tempat pelaksanaan program yang berada di lembaga PKBM tersebut dengan memanfaatkan ruang yang representatif untuk pelaksanaan program. Hal ini dapat dilihat dari 8 (delapan) jenis inovasi program PNF yang dikembangkan terdapat 6 (enam) program yang memiliki locus didalam lembaga PKBM dan hanya 2 (dua) program saja yang berada diluar lembaga PKBM.

Jika ditinjau dari dimensi fokusnya, maka inovasi program-pogram yang ada dapat dikelompokkan kedalam sejumlah kategori yang terkait dengan proses pelayanan, peningkatan kapasitas, dan peningkatan kesejahteraan masyarakat. Berdasarkan kategori tersebut, terdapat 2 (dua) program terkait dengan pelayanan, 1 (satu) program terkait dengan peningkatan kapasitas, dan 5 (lima) program terkait dengan peningkatan kesejahteraan masyarakat. Dilihat dari objektif yang ingin dicapainya, semua inovasi program yang dikembangkan oleh PKBMPKBM tersebut ditujukan untuk menangani permasalahan sosial ekonomi yang dihadapi oleh masyarakat sebagai sasaran programprogram PKBM. Sedangkan jika dilihat dari metode pelaksanaannya, maka inovasi program-program yang dikembangkan oleh PKBM-PKBM tersebut dapat dibagi kedalam kategori program yang dalam pelaksanannya melibatkan partisipasi masyarakat atau tidak melibatkan partisipasi masyarakat. Berdasarkan kategori tersebut, terdaat 6 (enam) program yang dalam pelaksanaannya melibatkan partisipasi masyarakat (sasaran program) dan hanya 2 (dua) program yang tidak melibatkan partisipasi masyarakat, hal ini disebabkan oleh program yang dikembangkan merupakan program yang telah ditentukan oleh Pengelola PKBM.

Inovasi program PNF yang dikembangkan oleh PKBM yang diteliti termasuk dalam tipe inovasi layanan, karena program yang dikembangkan merupakan program baru yang disesuaikan dengan kebutuhan belajar warga masyarakat. Jika dikaitkan dengan pengembangan pogram PNF, inovasi program yang telah diselenggarakan oleh PKBM tersebut lebih menekankan pada dimensi pendidikan kewirausahaan dengan fokus pengembangan potensi lingkungan berbasis ekonomi kreatif dan pengembangan pendidikan anak serta pendidikan keluarga. Selain itu, dengan mengacu pada penjabaran Undang-Undang nomor 20 tahun 2003 pasal 26 ayat (3), inovasi program PNF yang dikembangkan oleh PKBM yang diteliti lebih menekankan pada program Pendidikan Keterampilan, Pendidikan Kecakapan Hidup, Pendidikan Anak Usia Dini, dan Pendidikan lain yang berbasis pada kebutuhan masyarakat. Berikut pengelompokan inovasi program PNF yang diselenggarakan oleh PKBM di Kota Mataram. 
Jurnal Pendidikan dan Pemberdayaan Masyarakat, 3 (2), November 2016 - 192 Muhammad Arief Rizka, Rila Hardiansyah

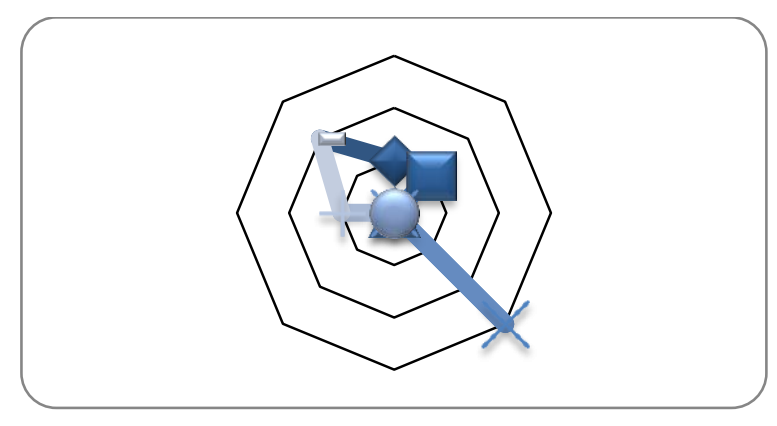

Gambar 1. Pengelompokan Inovasi Program PNF pada PKBM di Kota Mataram

\section{Strategi Pengembangan Inovasi Program PNF}

Dalam mengembangkan suatu program yang inovatif, diperlukan suatu strategi dan pendekatan yang dapat dijadikan sebagai landasan dalam melakukan pengembangan program. Pengembangan strategi tersebut menjadi salah satu hal penting untuk dapat merancang sekaligus merintis suatu program baru yang memiliki nilai kreasi dan inovatif. Keberhasilan dari PKBM-PKBM dalam melayani warga masayarakat, tentu tidak terlepas dari upaya-upaya PKBM tersebut untuk terus melakukan inovasi program. Untuk mengembangkan inovasi program tersebut, PKBM-PKBM yang menjadi lokasi penelitian memiliki strategi-strategi pengembangan program yang variatif. Namun yang menjadi persamannya, para Pengelola PKBM tersebut berupaya untuk menggunakan startegi partisipatif dengan melibatkan sasaran (masyarakat) untuk mendiskusikan programprogram yang akan dikembangkan.

Berdasarkan hasil wawancara dengan para Pengelola PKBM, dalam mengembangkan sebuah program baru di PKBM selalu mendepankan prinsip partisipatif dengan mensosialisasikan ide-ide dan gagasan baru khususnya kepada tokoh masyarakat dan sasaran, juga dengan pihak-pihak eksternal lainnya seperti penilik PLS, aktivitis sosial dan pendidikan, serta pihak-pihak yang peduli terhadap pendidikan masyarakat. Hal ini bertujuan untuk memperoleh dukungan baik moril maupun material terhadap penyelenggaraan program tersebut kedepan. Strategi partisipatif yang digunakan dalam mengembangkan suatu program inovatif di PKBM dilakukan melalui tahapan; (1) Pengelola PKBM bersama tokoh masyarakat mendiskusikan secara informal rencana pengembangan program baru dengan basis pada pemerhatian potensi lokal dan perkembangan kebutuhan belajar masyarakat; (2) Hasil dari diskusi informal perancangan program tersebut lalu dilanjutkan melalui komunikasi dengan Penilik PLS agar memperoleh masukan dan saran untuk memantapkan rancangan program; (3) setelah memperoleh masukan dan saran, Pengelola PKBM mulai memetakan jaringan kemitraan untuk dapat mendukung penyelenggaran program khususnya dalam membantu ketersediaan fasilitas, sumber daya manusia, maupun dukungan pasca pelaksanaan program; dan (4) Pengelola PKBM mulai melakukan pendataan calon warga belajar (sasaran) dan merancang kebutuhan komponen program lainnya dengan tetap melibatkan seluruh unsur yang ada di PKBM.

Sejauh ini, strategi partisipatif yang digunakan tersebut telah mendapatkan respon yang positif dari para stakeholders PKBM. Namun sisi kelemahan dalam aplikasi strategi tersebut yakni, inkonsistensi (ketidak-konsistenan) dalam implementasinya. Terkadang pengelola PKBM dalam mengembangkan suatu program, masih memiliki mindset ketergantungan, artinya jika ingin mengembangkan program yang baru harus ada dukungan dan jaminan dari pihak ekstenal seperti harus ada dana, fasilitas, dan sebagainya sehingga secara kuantitatif dan kualitatif program-program tersebut kurang berkembang secara maksimal.

Dalam mengembangkan programprogram PNF yang inovatif, selain menggunakan strategi partisipatif, beberapa PKBM yang menjadi unit analisis dalam penelitian ini juga berupaya melakukan penciptaan program pendidikan masyarakat lainnya dengan pola persuasif atau mengajak masyarakat untuk mengikuti program dengan sebelumnya Pengelola PKBM terlebih dahulu merancang program secara internal. 
Jurnal Pendidikan dan Pemberdayaan Masyarakat, 3 (2), November 2016 - 193

Muhammad Arief Rizka, Rila Hardiansyah

Tabel 3. Strategi Inovasi Program PNF

\begin{tabular}{cll}
\hline \multirow{2}{*}{ Nama PKBM } & \multicolumn{1}{c}{ Inovasi Program } & \multicolumn{1}{c}{$\begin{array}{c}\text { Strategi Inovasi } \\
\text { Program }\end{array}$} \\
\hline \multirow{2}{*}{ Al-Kautsar } & Pelatihan keterampilan asesoris perahu nelayan & Strategi Partisipatif \\
\cline { 2 - 3 } & $\begin{array}{l}\text { Pemberdayaan perempuan melalui pelatihan kewirausahaan } \\
\text { berbasis pengolahan ikan laut }\end{array}$ & $\begin{array}{l}\text { Strategi Pemetaan } \\
\text { Sosial }\end{array}$ \\
\hline \multirow{2}{*}{ Al-Hidayah } & Pelatihan kecakapan hidup ternak ikan lele & Strategi Partisipatif \\
\cline { 2 - 3 } & Kursus modes busana muslim & Strategi Partisipatif \\
\hline Sinar Harapan & Kelompok Usaha Bersama (KUB) tata rias pengantin & Strategi Persuasif \\
\hline \multirow{2}{*}{ Terampil } & Bina keluarga sakinah & Strategi Persuasif \\
\cline { 2 - 3 } & Taman Anak Sejahtera (TAS) & Strategi Persuasif \\
\hline Sintung & Kelompok Belajar Usaha (KBU) aneka jajanan tradisional & Strategi Partisipatif \\
\hline
\end{tabular}

Dalam pelaksanaannya, penerapan strategi persuasif itu juga tidak dapat terlaksana dengan mudah. Hal ini disebabkan oleh masih adanya sebagian masyarakat yang belum memiliki pemahaman dan kesadaran dalam mendukung penyelenggaraan program-program pendidikan di masyarakat. Dengan kondisi tersebut menuntut kemampuan Pengelola PKBM untuk dapat mensosialisikan dan memberikan pemahaman komprehensif kepada warga masyarakat mengenai tujuan dan dampak dari program yang akan dilaksanakan.

Berdasarkan analisis data yang dilakukan dalam penelitian ini juga menjelaskan bahwa strategi lain yang digunakan oleh PKBM-PKBM di Kota Mataram untuk mengembangkan program PNF yang inovatif melalui proses pemetaan sosial dengan basis pada identifikasi potensi lingkungan (lokal) masyarakat. Strategi ini digunakan untuk lebih memudahkan Pengelola PKBM dalam menyelenggarakan program baik dalam hal menarik motivasi calon warga belajar dan mempersiapkan kebutuhan program (karena sumber daya yang dibutuhkan untuk pelaksanaan program berasal dari lingkungan masyarakat sekitar).

Untuk lebih memudahkan pemahaman terhadap strategi-strategi inovasi program PNF yang dilakukan oleh PKBM-PKBM (sebagai unit analisis penelitian) di Kota Mataram. Tabel 3 menunjukkan pemaparan secara ringkas strategi yang digunakan oleh masing-masing PKBM tersebut.

Berdasarkan Tabel 3, PKBM-PKBM di Kota Mataram yang menjadi unit analisis penelitian dalam mengembangkan programprogram inovatif berupaya menggunakan strategi-strategi tertentu. Strategi-strategi tersebut antara lain yakni strategi partisipatif, strategi persuasif, dan strategi pemetaan sosial. Pengggunaan dari masing-masing strategi tersebut disesuaikan dengan konteks potensi lingkungan masyarakat (sasaran). Strategi partisipatif lebih digunakan untuk mengembangkan program inovatif yang bersifat pengembangan (pelatihan) lifeskills (kecakapan hidup atau keterampilan) masyarakat, strategi persuasif digunakan untuk mengembangkan program yang bersifat ajakan kepada masyarakat untuk mengikuti pelaksanaan program yang sudah dirancang oleh Pengelola PKBM, dan strategi pemetaan sosial digunakan untuk mengembangkan progam inovatif yang berbasis pada identifikasi dan pendayagunaan potensi lokal untuk dikembangkan menjadi suatu program yang dapat memberikan nilai tambah bagi masyarakat.

\section{Pembahasan}

Pusat Kegiatan Belajar Masyarakat (PKBM) merupakan salah satu satuan Pendidikan Non Formal (PNF) yang secara konseptual berbasis masayarakat dan dituntut untuk selalu melakukan inovasi-inovasi untuk melahirkan program-program pemberdayaan masyarakat yang lebih baru, berkarakter transformatif, dan dapat menjadi best practice dengan tidak meninggalkan karakteristik kearifan dan keunggulan lokal sebagai added values untuk mencerdaskan dan sekaligus mensejahterahkan kehidupan masyarakat.

Dalam menyelenggarakan program pendidikan, PKBM dituntut untuk mengembangkan program-program PNF yang ino- 


\section{Jurnal Pendidikan dan Pemberdayaan Masyarakat, 3 (2), November 2016 - 194}

Muhammad Arief Rizka, Rila Hardiansyah

vatif sebagai manifestasi dari eksistensi PKBM yang ingin menjadi bagian strategis dalam pemecahan permasalahan yang ada dimasyarakat. Dalam mengatasi berbagai permasalahan kebutuhan belajar masyarakat tidak cukup hanya bertumpu pada programprogram pendidikan yang bersifat "instruksionalis', tetapi sangat penting untuk melakukan upaya-upaya improvisasi program bahkan sampai pada inovasi program yang berbasis pengembangan potensi individu dan lingkungan.

Inovasi program dalam konteks Pendidikan Non Fomal (PNF) menjadi suatu hal yang strategis karena program-program yang dikembangkan tersebut diharapkan dapat menjawab kebutuhan belajar masyarakat sebagai sasaran pembelajaran yang heterogen. Inovasi program yang dikembangkan melalui lembaga PKBM dapat dijadikan sebagai best pactices agar bisa direplikasi oleh satuan PNF lainnya sehingga terjalin sinergisitas dan kesinambungan dalam memecahkan permasalahan yang ada dimasyarakat.

Dalam implementasinya, karakteristik inovasi dari suatu program khususnya program Pendidikan Non Formal (PNF) terdiri atas empat hal (Miles, 1973, p. 14), yaitu: (1) Memiliki kekhasan/khusus, artinya suatu inovasi akan memiliki ciri yang khas dalam arti ide, program, tatanan, sistem, termasuk kemungkinan hasil yang diharapkan. (2) Memiliki ciri atau unsur kebaruan, dalam arti suatu inovasi harus memiliki karakteristik sebagai hasil karya dan pemikiran yang original. (3) Program inovasi dilaksanakan melalui program yang terencana yang lebih sistematis dan dipersiapkan secara matang. (4) Inovasi yang digulirkan memiliki tujuan, termasuk arah dan strategi untuk mencapai suatu tujuan dari sistem inovasi yang dilakukan.

Inovasi program PNF yang dikembangkan oleh PKBM yang diteliti termasuk dalam tipe inovasi layanan, karena program yang dikembangkan merupakan program baru yang disesuaikan dengan kebutuhan belajar warga masyarakat. Jika dikaitkan dengan pengembangan program PNF, inovasi program yang telah diselenggarakan oleh PKBM tersebut lebih menekankan pada dimensi pendidikan kewirausahaan dengan fokus pengembangan potensi lingkungan berbasis ekonomi kreatif dan pengembangan pendidikan anak serta pendidikan keluarga. Selain itu, dengan mengacu pada penjabaran Undang-Undang nomor 20 tahun 2003 pasal 26 ayat (3), inovasi program PNF yang dikembangkan oleh PKBM yang diteliti lebih menekankan pada program Pendidikan Keterampilan, Pendidikan Kecakapan Hidup, Pendidikan Anak Usia Dini, Pendidikan Pemberdayaan Perempuan, dan Pendidikan lain yang berbasis pada kebutuhan masyarakat.

Dalam mengembangkan inovasi program, PKBM-PKBM di Kota Mataram memiliki strategi tertentu untuk dapat mengkreasikan program PNF yang inovatif. Pengembangan strategi tersebut menjadi salah satu hal penting untuk dapat merancang sekaligus merintis suatu program baru yang memiliki nilai kreasi dan inovatif. Keberhasilan dari PKBM-PKBM tersebut dalam melayani warga masayarakat, tentu tidak terlepas dari upaya-upaya PKBM tersebut untuk terus melakukan inovasi program. Untuk mengembangkan inovasi program tersebut, PKBM-PKBM yang menjadi lokasi penelitian memiliki strategi-strategi pengembangan program yang variatif. Namun yang menjadi persamannya adalah para Pengelola PKBM tersebut berupaya untuk menggunakan strategi partisipatif dengan melibatkan sasaran (masyarakat) untuk mendiskusikan program-program yang akan dikembangkan.

Strategi partisipatif yang digunakan dalam mengembangkan suatu program inovatif di PKBM dilakukan melalui tahapan; (1) Pengelola PKBM bersama tokoh masyarakat mendiskusikan secara informal rencana pengembangan program baru dengan basis pada pemerhatian potensi lokal dan perkembangan kebutuhan belajar masyarakat; (2) Hasil dari diskusi informal perancangan program tersebut lalu dilanjutkan melalui komunikasi dengan Penilik PLS agar memperoleh masukan dan saran untuk memantapkan rancangan program; (3) setelah memperoleh masukan dan saran, Pengelola PKBM mulai memetakan jaringan kemitraan untuk dapat mendukung penyelenggaran program khususnya dalam membantu ketersediaan fasilitas, sumber daya manusia, 


\section{Jurnal Pendidikan dan Pemberdayaan Masyarakat, 3 (2), November 2016 - 195}

Muhammad Arief Rizka, Rila Hardiansyah

maupun dukungan pasca pelaksanaan program; dan (4) Pengelola PKBM mulai melakukan pendataan calon warga belajar (sasaran) dan merancang kebutuhan komponen program lainnya dengan tetap melibatkan seluruh unsur yang ada di PKBM.

Selain menggunakan strategi partisipatif, beberapa PKBM yang menjadi unit analisis dalam penelitian ini juga berupaya melakukan penciptaan program pendidikan masyarakat lainnya dengan pola persuasif atau mengajak masyarakat untuk mengikuti program. Berdasarkan analisis data yang dilakukan dalam penelitian ini juga menjelaskan bahwa strategi lain yang digunakan oleh PKBM-PKBM di Kota Mataram untuk mengembangkan program PNF yang inovatif melalui proses pemetaan sosial dengan basis pada identifikasi potensi lingkungan (lokal) masyarakat. Strategi ini digunakan untuk lebih memudahkan Pengelola PKBM dalam menyelenggarakan program baik dalam hal menarik motivasi calon warga belajar dan mempersiapkan kebutuhan program (karena sumber daya yang dibutuhkan untuk pelaksanaan program berasal dari lingkungan masyarakat sekitar).

Dalam upaya untuk mengembangkan inovasi program PNF, terdapat kendalakendala yang dihadapi oleh Pengelola PKBM baik yang bersifat kendala internal maupun kendala eksternal. Berdasarkan pada temuan penelitian ini, kendala yang dihadapi dalam mengembangkan program-program PNF yang inovatif lebih kepada keterbatasan kemampuan atau kapasitas sumber daya manusia PKBM dalam membaca peluangpeluang atau potensi sumber daya lokal (masyarakat) untuk dapat dikembangkan menjadi program pendidikan yang dapat memberikan nilai tambah dan peningkatan kualitas kehidupan masyarakat. Selanjutnya keterbatasan kemampuan yang dimiliki oleh Pengelola PKBM tersebut adalah kemampuan dalam aspek manajerial, yakni kemampuan Pengelola PKBM untuk mengorganisasikan program PNF yang inovatif untuk dapat terlaksana dengan prinsip pada mutu dan profesionalitas. Selain itu, masih minimnya mitra kerja PKBM sehingga kurang mampu untuk mendiskusikan program-program yang kreatif dan memiliki nilai prospektif.
Kendala yang dihadapi juga terletak pada masih minimnya partisipasi dari tokoh masyarakat untuk terlibat aktif dalam pengembangan program PNF di PKBM. Partisipasi tokoh masyarakat dalam penyelenggaraan program PNF di PKBM masih terbatas pada partisipasi dalam bentuk moril, belum secara utuh untuk dapat berpartisipasi dalam hal sumbang pemikiran, gagasan-gagasan kreatif, maupun memberikan masukan konstruktif untuk pengembangan eksistensi PKBM secara komprehensif. Dapat diketahui bahwa tokoh masyarakat merupakan bagian kunci dari masyarakat yang memahami dengan baik kondisi, karakteristik, potensi lokal, dan keunggulan-keunggulan yang dimiliki oleh wilayah tersebut sehingga pengetahuan dan pemahaman terhadap pengembangan program yang berbasis pada keunggulan lokal seharusnya dapat dirancang dan diimplementasikan secara optimal. Selain itu, tokoh masyarakat juga memiliki kapasitas dalam hal memobilisasi ketersediaan sumber daya yang berada disuatu wilayah sehingga dapat dijadikan salah satu faktor pendukung untuk pengembangan program PNF yang inovatif. Disamping masih minimnya partisipasi dari tokoh masyarakat, temuan dalam penelitian ini juga menjelaskan bahwa masih minimnya keterlibatan warga masyarakat (sebagai sasaran program) dalam melakukan perancangan (pengelolaan) program PNF di PKBM secara keseluruhan, sehingga mengakibatkan gagasan-gagasan kreatif yang dimiliki oleh warga belajar dalam membantu mengembangkan suatu program yang inovatif kurang terakomodir dengan baik. Posisi warga belajar (masyarakat) lebih kepada objek dari penyelenggara program artinya hanya menerima perancangan program yang telah dikembangkan oleh Pengelola PKBM.

\section{SIMPULAN}

Inovasi program PNF yang dikembangkan oleh PKBM-PKBM di Kota Mataram cukup variatif dan berbasis pada kebutuhan riil masyarakat dengan fokus inovasi program pada dimensi pelayanan, peningkatan kapasitas, dan kesejahteraan masyarakat. Adapun bentuk inovasi program PNF yang dikembangkan tersebut antara lain yaitu; (a) program pelatihan keterampilan asesoris perahu 


\section{Jurnal Pendidikan dan Pemberdayaan Masyarakat, 3 (2), November 2016 - 196}

Muhammad Arief Rizka, Rila Hardiansyah

nelayan; (b) program pemberdayaan perempuan melalui pelatihan kewirausahaan berbasis pengolahan ikan laut; (c) program pelatihan kecakapan hidup ternak ikan lele; (d) program kursus modes busana muslim; (d) program Kelompok Usaha Bersama (KUB) tata rias pengantin; (e) program bina keluarga sakinah; (f) program taman anak sejahtera; dan Program Kelompok Belajar Usaha (KBU) aneka jajanan tradisional.

Strategi yang digunakan dalam pengembangan inovasi program PNF pada PKBM di Kota Mataram memiliki variasi sesuai dengan konteks dan karakteritik sasaran (masyarakat), strategi yang digunakan oleh PKBM dalam melakukan inovasi program PNF antara lain yaitu startegi partisipatif, strategi persuasif, dan strategi pemetaan sosial yang dimana penggunaan strategi tersebut sejauh ini cukup optimal dalam mengembangkan program PNF yang inovatif di masing-masing PKBM tersebut.

\section{DAFTAR PUSTAKA}

BPPNFI Regional VII Mataram. (2010). Deskripsi analisis data pendidikan non formal dan informal berbasis SIM PNFI. Kemdiknas. Dirjen PNFI.

Departemen Pendidikan Nasional. (2003). Undang-undang sistem pendidikan nasional tahun 2003. Jakarta: Sinar Grafika Offset.
Miles, M. B. (1973). Innovation in education. New York: Teacher College Press, Columbia University.

Miles, M. B., \& Huberman, A. M. (2007). Analisis data kualitatif. (Terjemahan Tjetjep Rohendi Rohindi). Jakarta: Penerbit Universitas Indonesia.

Moleong, L. J. (2007). Metodologi penelitian kualitatif. rev. ed. Bandung: PT. Remaja Rosdakarya.

Mulyana, D. (2001). Metodologi penelitian kualitatif. Bandung: PT Remaja Rosdakarya.

Rizka, M. A., \& Tamba, W. (2015). Pemetaan inovasi program pendidikan non formal (PNF) pada pusat kegiaan belajar masyarakat (PKBM) di Kota Matatram. Jurnal Transformasi Volume 1 Nomor 1 Edisi Maret 2015. ISSN: 2442-5842.

Suharta, RB., dkk. (2009). Evaluasi pelaksanaan program-program pendidikan nonformal pada PKBM. Lemlit UNY Yogyakarta.

Tohani, E. (2010). Evaluasi kelembagaan PKBM di Kabupaten Bantul DIY. Jurnal VISI PTK-PNF Volume 5 Nomor 2 Desember 2010.

Unesco. (2007). Strengthening community learning centre through linkages and networks: A synthesis of six country reports. Bangkok: Unesco Asia and Pasific Regional Bureau for Education. 